\title{
ORTHODOX CHRISTIANITY AND NATIONALISM IN NINETEENTH-CENTURY SOUTHEASTERN EUROPE
}


This page intentionally left blank 


\title{
ORTHODOX CHRISTIANITY AND CONTEMPORARY THOUGHT
}

\author{
SERIES EDITORS \\ George E. Demacopoulos and Aristotle Papanikolaou
}

This series consists of books that seek to bring Orthodox Christianity into an engagement with contemporary forms of thought. Its goal is to promote (1) historical studies in Orthodox Christianity that are interdisciplinary, employ a variety of methods, and speak to contemporary issues; and (2) constructive theological arguments in conversation with patristic sources and that focus on contemporary questions ranging from the traditional theological and philosophical themes of God and human identity to cultural, political, economic, and ethical concerns. The books in the series explore both the relevancy of Orthodox Christianity to contemporary challenges and the impact of contemporary modes of thought on Orthodox self-understandings. 


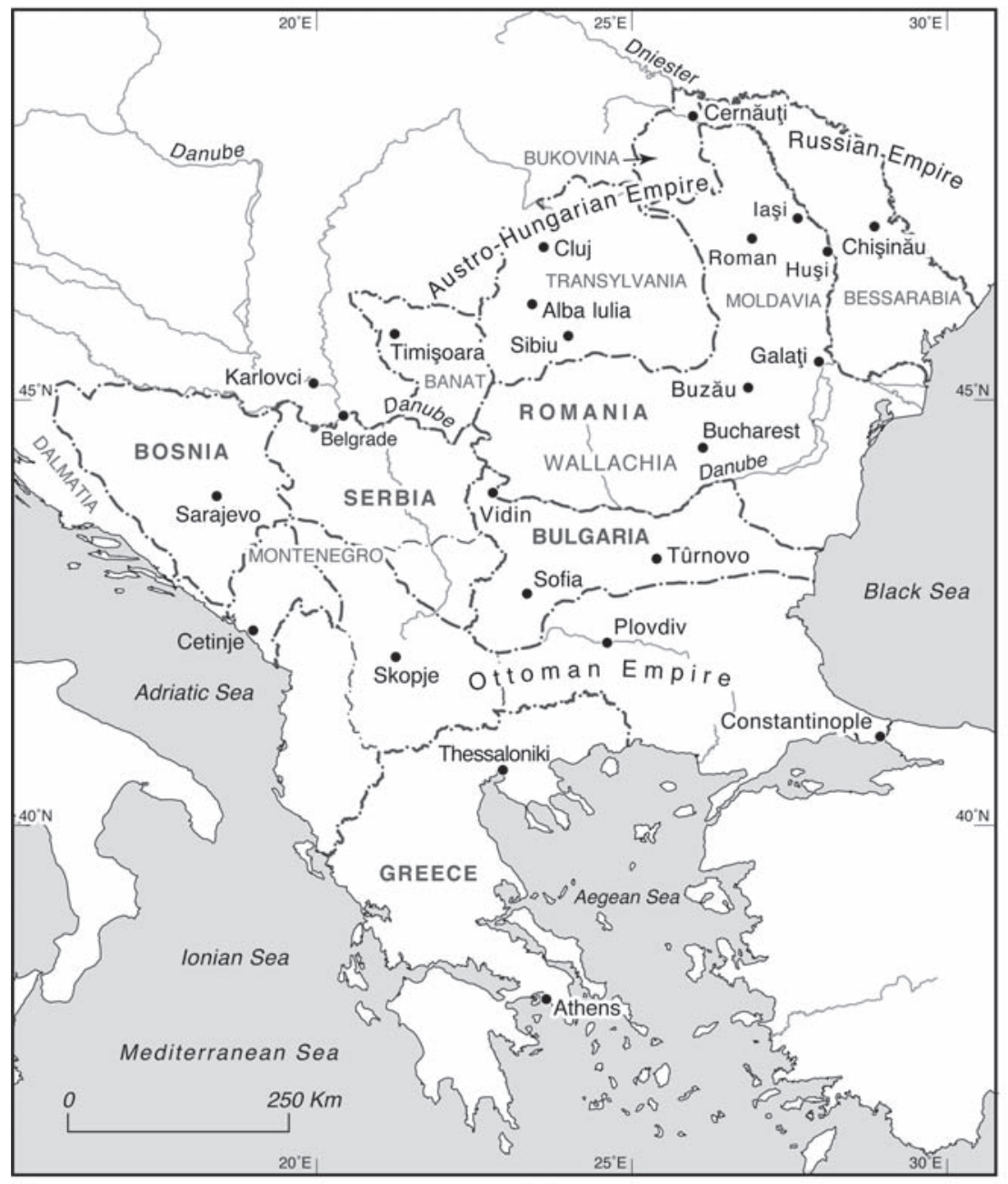




\title{
ORTHODOX \\ CHRISTIANITY AND \\ NATIONALISM IN \\ NINETEENTH- \\ CENTURY \\ SOUTHEASTERN \\ EUROPE
}

\author{
EDITED BY \\ LUCIAN N. LEUSTEAN
}

FORDHAM UNIVERSITY PRESS

New York • 2014 
Frontispiece: Southeastern Europe in the nineteenth century (Source: Mina Moshkeri Upton, LSE Design Unit)

Copyright () 2014 Fordham University Press

All rights reserved. No part of this publication may be reproduced, stored in a retrieval system, or transmitted in any form or by any means-electronic, mechanical, photocopy, recording, or any other-except for brief quotations in printed reviews, without the prior permission of the publisher.

Fordham University Press has no responsibility for the persistence or accuracy of URLs for external or third-party Internet websites referred to in this publication and does not guarantee that any content on such websites is, or will remain, accurate or appropriate.

Fordham University Press also publishes its books in a variety of electronic formats. Some content that appears in print may not be available in electronic books.

Library of Congress Cataloging-in-Publication Data is available from the publisher.

Printed in the United States of America

$161514 \quad 5 \quad 4 \quad 321$

First edition 